\title{
Newborn Screening for Sickle Cell Disease (SCD) in Awka South East Nigeria
}

\author{
Ejiofor OS ${ }^{1}$, Efobi $\mathrm{C}^{2}$, Emechebe $\mathrm{GO}^{1}$, Ifezulike $\mathrm{CC}^{1}$, Okeke $\mathrm{KN}^{1}$, Mokebe $\mathrm{TC}^{3}$, Obijiofor $\mathrm{K}^{3}$, Ideh $\mathrm{CC}^{3}$ and Onuh $\mathrm{U}^{3}$ \\ ${ }^{1}$ Department of Paediatrics, Chukwuemeka Odumegwu Ojukwu University Teaching Hospital, Awka, Nigeria \\ ${ }^{2}$ Department of Hematology, Chukwuemeka Odumegwu Ojukwu University, Awka, Nigeria \\ ${ }^{3}$ Sickle cell disease Unit, Chukwuemeka Odumegwu Ojukwu University teaching hospital, Awka, Nigeria
}

*Corresponding author: Efobi C, Department of Paediatrics, Chukwuemeka Odumegwu Ojukwu University Teaching Hospital, Awka, Anambra State, Nigeria, Tel: +7401201278, E-mail: chylowb@yahoo.com

Received date: 15 Mar 2018; Accepted date: 30 Mar 2018; Published date: 04 Apr 2018

Copyright: @ 2018 Ejiofor OS, et al. This is an open-access article distributed under the terms of the Creative Commons Attribution License, which permits unrestricted use, distribution, and reproduction in any medium, provided the original author and source are credited.

\begin{abstract}
Background: Sickle cell Diseases (SCD) is a genetic disorder. It is the most common genetic disorder affecting black race worldwide. It carries a high mortality and morbidity when not promptly and properly managed. Early detection is key to improving the quality of life of people living with sickle cell disease especially in childhood. It has resulted in reduction in mortality rate of SCD to $<1 \%$ in developed countries through new-born screening but this reduction is yet to be achieved in developing countries.
\end{abstract}

Objective: To share the experience of new-born screening of SCD at COOUTH Awka. To determine the prevalence of Sickle cell disease among neonates in Anambra State.

Methodology: A retrospective study of screening for SCD in new-borns carried out at Chukwuemeka Odumegwu Ojukwu University Teaching Hospital (COOUTH) Awka from $1^{\text {st }}$ September 2013 to $27^{\text {th }}$ October 2017. This was done using isoelectric focusing machine.

Results: A total of 4961 children were screened, 2410 were males, while 2551 were females. $75 \%(3733)$ of the neonates had their hemoglobin genotypes as AA, while $0.3 \%(16)$ were $\mathrm{Hb}$ SS genotype. Prevalence of $\mathrm{Hb}$ SS genotype amongst newborns was $0.32 \%$.

Conclusion: This study found the prevalence of sickle cell disease in newborns to be $0.32 \%$. Newborn screening using Isoelectric focusing machine is very valuable for early diagnosis and prompt management of SCD. There is therefore need for increased awareness of this in Anambra State.

\section{Key words:}

Sickle cell disease; New-born screening; Isoelectric focusing; Early detection

\section{Introduction}

Sickle cell disease (SCD) is an increasing public health problem. It is estimated that every year approximately 300,000 infants are born with sickle cell disease [1]. It is a genetic disorder and is the most common genetic disorder that affects black race worldwide [2]. Nigeria is one of the countries with a high incidence of sickle cell disease. Others include the Democratic republic of Congo and India [1].

SCD is an inherited condition, where an individual inherits two abnormal haemoglobins from the parents, one of which is Hemoglobin S. The clinical manifestations arise from the tendency of the hemoglobin (HbS or sickle hemoglobin) to form polymers and deform red blood cells into the characteristic sickle shape [3]. The effects of the sickling process include: membrane changes resulting in potassium loss and cellular dehydration, interaction of Hemoglobin S with micro vascular endothelium, neutrophils, and monocytes, hemolysis with resultant nitric oxide depletion, as well as release of inflammatory proteins and activation of coagulation pathway. These processes are responsible for the clinical manifestations of sickle cell disease and the subsequent complications that affect multiple organ systems leading to shortened life expectancy [4]. Many of the complications of sickle cell disease mostly affect and kill young children before the diagnosis is made.

The most common and most severe form of sickle cell disease is hemoglobin SS disease also called sickle cell anemia [5]. The less common ones include SC disease, SBO-thalassemia and SB+ thalassemia, etc.

It has been reported that 20-25 million people worldwide live with SCD, of which 12-15 million live in Africa. It has also been estimated that $75-85 \%$ of children born with SCD are born in Africa, where under 5 mortality rates range from $50 \%$ to $80 \%[6,7]$. Some countries that have introduced early interventions like newborn screening, prevention of infections and comprehensive care have achieved significant reductions in mortality; with up to $94 \%$ surviving to 18 years in the United States of America (USA) and $99 \%$ to 20 years in the UK interventions, but this has not been achieved in African countries due to lack of locally appropriate data and studies on sickle cell disease $[8,9]$. It has been estimated by the WHO that over two- thirds of 
Page 2 of 3

deaths caused by sickle cell disease in Africa are preventable with simple, cost-effective interventions such as early detection of SCD patients through newborn screening (NBS) and early intervention via immunizations, prophylaxis against infections using penicillin and prompt treatment of acute events, as well as health education of care givers and patients. In order to improve the quality of life, prevent frequent hospital visits and reduce mortality in SCD patients, early diagnosis through newborn screening is of utmost importance. It also entails initiating appropriate early intervention and comprehensive care. So far, no study on newborn screening for SCD has been done in Awka, Anambra State. This underscores the need for this study. Information obtained may form basis for health education for parents on the importance of SCD screening. It will also increase knowledge on newborn SCD Screening and form basis for future research.

\section{Materials and Methods}

This is a retrospective study done at Chukwuemeka Odumegwu Ojukwu University Teaching Hospital (COOUTH) Awka which is a tertiary Health Facility owned by Anambra State Government that cater for the health needs of the people of the state and its environs. It is a 200 bed capacity hospital. The program commenced in September 2013 and is still on. A 4 year review of the screening done from September 2013 to October 2017 was carried out from the records of the screening laboratory. Ethical clearance was duly obtained from COOUTH Awka before commencement of the study. The SCD screening was done by determining hemoglobin genotype using Isoelectric focusing eletrophoresis machine.

have FS (that is $\mathrm{HbF}$ and $\mathrm{HbS}$ ) were referred to pediatric sickle cell clinic for follow up and management. Information obtained from the laboratory register include number of those screened and found to have abnormal hemoglobin genotypes, their ages and sexes as well as the total number of those screened with their ages and sexes. Parents and Guardians whose children had abnormal hemoglobin genotypes were counseled on the nature of the disease and subsequently referred to SCD clinic for follow up and management. Analysis of the data was done in simple proportions and results presented in tables.

\section{Results}

A total of 4961 newborns were screened, of which 2,410 were males, while 2551 were females giving a male: female ratio of 1:1.1. as seen in Table 1. Most of the neonates (75.2\%) had hemoglobin AA genotype, while about a quarter $(24.3 \%)$ were hemoglobin AS. Only $16(0.3 \%)$ neonates were found to have sickle cell disease as shown in Table 2. Figure 1 showed a gel image of hemoglobin electrophoresis done by isoelectric focusing. The females were more across all the hemoglobin genotype distributions amongst the neonates as seen in Table 3.

\begin{tabular}{|l|l|l|}
\hline S/N & Variables & $\mathbf{N}=4961$ \\
\hline 1 & Sex & $2410(48.6)$ \\
\hline & Males & $2551(51.4)$ \\
\hline & Females & \multicolumn{2}{|l|}{} \\
\hline 2 & Age & $4961(100 \%)$ \\
\hline & $0-30$ days &
\end{tabular}

Table 1: Demographic variables of the study population.

\begin{tabular}{|l|l|l|}
\hline Genotype & Total $\mathbf{N}=\mathbf{4 9 6 1}$ & frequency (\%) \\
\hline Hb AA & 3733 & 75.2 \\
\hline HB AS & 1208 & 24.3 \\
\hline HB SS & 16 & 0.32 \\
\hline HB AC & 4 & 0.08 \\
\hline
\end{tabular}

Table 2: Hemoglobin genotype distribution by sex of the study population.

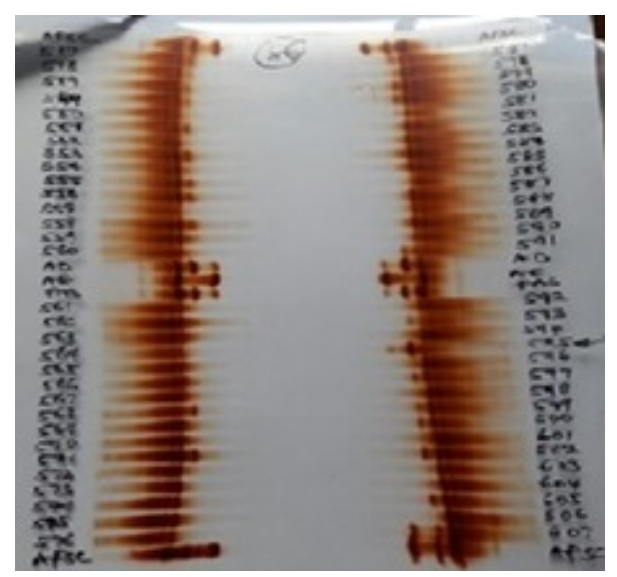

Figure 1: Gel images of IEF demonstrates the quality of the blood samples.

\begin{tabular}{|l|l|l|l|l|}
\hline Hemoglobin Genotype & Total=4916 & Frequency(\%) & Male & Female \\
\hline HBAA & 3733 & 75.2 & 1310 & 2423 \\
\hline HBAS & 1208 & 24.3 & 583 & 595 \\
\hline HBSS & 16 & 0.32 & 7 & 9 \\
\hline HBAC & 4 & 0.08 & 1 & 3 \\
\hline
\end{tabular}

Table 3: Genotype distribution by age of the population.

\section{Discussion}

Newborn screening for sickle cell disease (SCD) using Isoelectric focusing machine is very valuable in screening for this genetic disorder. Early diagnosis of SCD may be missed if the routine cellulose acetate electrophoresis which is unable to accurately determine hemoglobin phenotype before three months of age is relied upon especially for these neonates and infants. This could lead to due to delay in prompt diagnosis and early intervention. To improve SCD patient care in south eastern Nigeria, newborn screening for SCD is apparently an urgently needed service as reported in this manuscript.

The number of neonates screened for sickle cell disease in this study was 4961. This varied with what was obtainable in similar studies [10-14]. This may be due to differences in duration of study, type of health institution used as well as level of awareness of newborn screening program in the community. 
Majority of those screened were females. , Odunvbun et al $[10,11]$ recorded a higher number of males.

As shown in this study, overall prevalence of SCD in newborns at $0.3 \%$ was low compared to other studies [10,11,13-19]. These differences could be due to the various methods of hemoglobin detection used in the different studies like isoelectric focusing, cellulose acetate electrophoresis, high performance liquid chromatography, etc. These methods may have varying degrees of sensitivity in detecting $\mathrm{HbF}$ and $\mathrm{HbS}$ in newborns. Blood test for screening at Benin was done with Isoelectric focusing machine as is the case in this study, while the one from Northern Nigeria was done with High Performance Liquid Chromatography (HPLC). It may also be due to problems resulting from stored blood samples as well as poor utilization and low level of awareness of newborn screening in Anambra state. There is therefore need for increased awareness so as to obtain the actual prevalence of SCD especially in newborns. On the contrary, it may also be attributed to the fact that more HbS carriers now marry HbAA individuals in a bid to avoid having SCD children. This has also been made compulsory by some religious institutions. We also noted that the prevalence of SCD in this study was higher than that reported in some parts of Spain [20].

The low level of Hemoglobin $\mathrm{C}(\mathrm{HbC})$ noted in this study when compared to earlier and recent studies showed that the low incidence of $\mathrm{HbC}$ in the East of the River Niger has not changed over the years [21-23] when compared with Midwestern Nigeria [24]. It is believed that sustaining the new born screening for sickle cell disease will improve life expectancy for those with sickle cell disease in Nigeria through early diagnosis and intervention.

\section{Conclusion}

This study showed a poor awareness for newborn screening for sickle cell disease. The mortality associated with sickle cell disease in Nigeria can be reduced significantly through early detection via this newborn screening and subsequent follow up. This calls for the urgent need to increase the awareness of newborn screening for sickle cell disease so that reduction in mortality associated with SCD as well as improved quality of life can be achieved.

\section{References}

1. Piel FB, Patil AP, Howes RE, Nyangiri OA, Gething PW, et al. (2013) Global epidemiology of sickle haemoglobin in neonates: A contemporary geostatistical model-based map and population estimates. Lancet 381: 142-151.

2. Diallo D, Tchernia G (2002) Sickle cell disease in Africa. Curr Opin Hematol 9: 111-116.

3. Ashutosh L, Elliott PV (2011) Sickle cell disease in: Postgraduate hematology. Editors:Hoffbrand VA, Catovsky D, Tuddenham EGD, Green A. 6th edition. Wiley- Blackwell publishing ltd. Chapter 7: 109-124.

4. Natrajan K, Kutlar A (2016) Disorders of haemoglobin structure: Sickle cell anemia and related abnormalities. Williams Hematology 9th edition, McGraw-Hill Global Education: 759-788.
5. Grosse SD, Odame I, Atrash HK, Amendah DD, Piel FB, et al. (2011) Sickle cell disease in Africa: A neglected cause of early childhood mortality. Am J Prev Med 41: 398-405.

6. Aygun, B, Odame, I (2012) A global perspective on sickle cell disease. Pediatr Blood Cancer 59: 386-390.

7. Makani J, Cox SE, Soka D, Komba AN, Oruo J, et al. (2011) Mortality in sickle cell anemia in Africa: A prospective cohort study in Tanzania. PLoS One 6: 14699 .

8. Quinn CT, Rogers ZR, Buchanan GR (2004) Survival of children with sickle cell disease. Blood 103: 4023-4027.

9. Telfer P, Coen P, Chakravorty S, Wilkey O, Evans J, et al. (2007) Clinical outcomes in children with sickle cell disease living in England: A neonatal cohort in East London. Haematologica 92: 905-912.

10. Inusa BPD, Daniel Y, Lawson JO, Dada J, Mattehews CE, et al. (2015) Sickle cell disease screening in Northern Nigeria: The co-existence of Bthalassemia inheritance. Pediat Ther 5: 262

11. Odunvbun ME, Okolo AA, Rahimy CM (2008) Newborn screening for sickle cell disease in Nigeria hospital. Public Health 122: 1111-1116.

12. Mutesa L, Boemer F, Ngendahayo L, Rulisa S, Rusingiza EK, et al. (2007) Neonatal screening for sickle cell disease in Central Africa: A study of 1825 newborns with a new enzyme-linked immunosorbent assay test. J Med Screen 14: 113-116.

13. Tubman VN, Marshall R, Jallah W, Guo D, Ma C, et al. (2016) Newborn screening for sickle cell disease in Liberia: A pilot study. Pediatr Blood Cancer 63: 671-676.

14. Diwe K, Iwu AC, Uwakwe K, Duru C, Merenu I, et al (2016) Prevalence and patterns of sickle cell disease among children attending tertiary and non-tertiary health care institutions in a South Eastern State, Nigeria: A 10 year survey. J Res Med Den Sci 4: 183-189.

15. Danquah I, Ziniel P, Eggelte TA, Ehrhardt S, Mockenhaupt FP (2010) Influence of haemoglobins $\mathrm{S}$ and $\mathrm{C}$ on predominantly asymptomatic Plasmodium infections in northern Ghana. Trans R Soc Trop Med Hyg 104: 713-719.

16. Simpore J, Pignatelli S, Barlati S, Musumeci S (2002) Modification in the frequency of $\mathrm{Hb} \mathrm{C}$ and $\mathrm{Hb} \mathrm{S}$ in Burkina Faso: An influence of migratory fluxes and improvement of patient health care. Hemoglobin 26: 113-120.

17. Ndeezi G, Kiyaga C, Hernandez AG, Munube D, Howard TA, et al. (2016) Burden of sickle cell trait and disease in the Uganda sickle surveillance study (US3): A cross-sectional study. Lancet Glob Health 4: 195-200.

18. Arty G, Seth R, Bodas P, Zen LD, Zanolli FA, et al. (2012) Prevalence of sickle cell disease, Hemoglobin $S$, and Hemoglobin C among Haitian newborns: Feasibility of newborn screening for hemoglobinopathies in haiti. Blood 120: 4235.

19. Pereira MM, Corrons JL (2009) Neonatal haemoglobinopathy screening in Spain. J Clin Pathol 62: 22-25.

20. Kaine WN, Udeozo IOK (1981) Incidence of sickle cell trait and anemia in ibo pre-school children. Nig J Paed 8: 87-89.

21. Walters JH, LehMann H (1956) Distribution of S and C haemoglobin variants in two Nigerian communities. Trans Roy Soc Trop Med Hyg 50: 204-248.

22. Emechebe GO, Onyire NB, Orji ML, Achigbu KI (2017) Sickle cell disease in Nigeria: A review. IOSR J Dent Med Sci 16: 87-94.

23. Akinyanju OO (1989) A profile of sickle cell disease in Nigeria. Ann N Y Acad Sci 565: 126-136.

24. Makani J, Cox SE, Soka D, Komba AN, Oruo J, et al. (2011) Mortality in sickle cell anemia in Africa: A prospective cohort study in Tanzania 6. 